\title{
No, they didn't? Oh, they did!
}

\author{
Citation for published version (APA):
}

Verhallen, P. F. E. (2021). No, they didn't? Oh, they did! Advancing insights on social norm interventions in consumer financial decision-making. [Doctoral Thesis, Maastricht University]. Ipskamp. https://doi.org/10.26481/dis.20210628pv

Document status and date:

Published: 01/01/2021

DOI:

$10.26481 /$ dis.20210628pv

Document Version:

Publisher's PDF, also known as Version of record

\section{Please check the document version of this publication:}

- A submitted manuscript is the version of the article upon submission and before peer-review. There can be important differences between the submitted version and the official published version of record.

People interested in the research are advised to contact the author for the final version of the publication, or visit the DOI to the publisher's website.

- The final author version and the galley proof are versions of the publication after peer review.

- The final published version features the final layout of the paper including the volume, issue and page numbers.

Link to publication

\footnotetext{
General rights rights.

- You may freely distribute the URL identifying the publication in the public portal. please follow below link for the End User Agreement:

www.umlib.nl/taverne-license

Take down policy

If you believe that this document breaches copyright please contact us at:

repository@maastrichtuniversity.nl

providing details and we will investigate your claim.
}

Copyright and moral rights for the publications made accessible in the public portal are retained by the authors and/or other copyright owners and it is a condition of accessing publications that users recognise and abide by the legal requirements associated with these

- Users may download and print one copy of any publication from the public portal for the purpose of private study or research.

- You may not further distribute the material or use it for any profit-making activity or commercial gain

If the publication is distributed under the terms of Article $25 \mathrm{fa}$ of the Dutch Copyright Act, indicated by the "Taverne" license above, 


\section{SUMMARY}

Social norm interventions are a convenient, cost-effective method to drive behavioral change in consumer financial decision-making (retirement planning, saving) through all communication channels - whether online, in print, or in-app. Still, such interventions are not always effective, and have even resulted in unplanned oppositional reactions, where targeted consumers have behaved oppositional to the norm. This dissertation investigates the mechanics and boundary conditions of peer effects from social norm interventions, to fulfill three research objectives. First, I examine social norm interventions in a numeric financial decision-making context, disentangling the peer effect from the anchoring effect, and look at the role of consumer differences in susceptibilities to normative and informational influences on both the peer and anchoring effects. Second, I examine the effect of peer group characteristics in social norm interventions, and particularly relative to the aforementioned consumer differences. Third, I examine the effect of social norm characteristics, specifically the level of the salient behavior itself relative to consumers' current behavior, in social norm interventions. Through our increased understanding of peer effects from social norm interventions, we show opportunity for significantly stronger peer effects by tailoring interventions to the heterogeneous needs of the consumer, as witnessed by the retirement and savings (field) experiments from this dissertation research.

In Chapter 2, I employ two research questions to advance knowledge of social norm interventions. First, I test the anchoring effect against the peer effect from social norm interventions. Descriptive information of peers' behavior is used to nudge individuals to behave according to a norm. Since such descriptive information is often a quantitative metric, it is possible that any behavioral change is due to anchoring. Consequently, I disentangle peer and anchoring effects and test boundary conditions in two experimental studies with a retirement saving contribution rate scenario. In a first lab study with 295 participants, I find a strong similarity between a peer and anchoring effect. In a follow-up study with 663 participants, no anchoring effect is found when 
values (peer norms or anchors) more distant from the control group behavior are used, whereas the peer effect remains present. Second, I test and find evidence that the informational component - as opposed to the normative component - of peer information plays a stronger role for peer effects in financial decision-making.

In Chapter 3, I delve into the question of why social norm interventions have not always, and not for everyone, been effective. I propose that the alignment of specific salient reference group characteristics to specific consumer traits underlies the effectiveness of peer effect interventions. Specifically, I look at two channels of influence: a normative and an informational channel. I test whether consumers' perceived social identification with and source credibility of reference groups interact with consumers' susceptibilities to normative and informational influence. First, I identify which reference group attributes (e.g., age, work sector) have the largest impact on social identification and source credibility as perceived by a broad sample of 1,466 pension fund participants. Next, I translate these results into peer effect interventions with 220 participants in the lab and 1161 participants from an online panel, where I find that higher social identification with a reference group results in norm convergence only if consumers' susceptibility to normative influence is high. Lastly, I test my theory in the field with tailored communication targeting 222,596 pension fund participants, and confirm that higher social identification with and source credibility of reference groups, through tailored peer effect interventions targeting subsets of a heterogeneous population, strengthens the peer effect. Compared to a control condition and a generic peer effect condition commonly used in industry, the tailored peer effect conditions in the field experiment increased the click-rate by 31 to 55 per cent.

In Chapter 4, I again address the larger question of why social norm interventions show substantial variation in their effectiveness, but from a different angle. Chapter 3 looked at the interaction of specific peer group characteristics with individual characteristics, keeping peer group behavior constant across conditions. In Chapter 4, I 
keep the peer group constant, and manipulate the behavior of peer groups. I posit that social identification with a peer group used in a social norm intervention is affected by the respective peer group's behavior made salient in the intervention. Specifically, I propose, and empirically confirm through an experiment with 372 participants, that the perceived distance between an individual's current behavior and a peer group's salient behavior affects the individual's social identification with this peer group, with potential to transform a peer group into a non-peer group, with consequences - which I term the U-turn effect. As social identification positively affects convergence to norm behavior, the negative effect of perceived behavioral distance on social identification thus indirectly negatively affects convergence to norm behavior. These results indicate that social identification is an endogenous, and not merely an exogenous, variable in social norm theory, and may be one explanation for the oppositional reactions found in recent social norm intervention literature.

The findings from chapters 2,3 , and 4 contribute to literature streams in social norms and persuasion, oppositional reactions, normative and informational influences, social identity theory, social identification, source credibility, anchoring, and consumer financial decision-making. My results have four main implications for the effective design of social norm interventions. First, marketers should use peer groups that are credible and with whom people identify. Second, when the aforementioned is not possible, marketers should study their target population for their susceptibilities to normative and informational influence, and use peer groups high on identification or credibility, respectively. Third, peer groups that people do not identify with should never be used in an intervention, as such a peer group can evoke an oppositional reaction in the target population. Lastly, marketers should be cautious that the behavior made salient in an intervention does not deviate too much from the target's current behavior. 